\title{
Albibacter methylovorans gen. nov., sp. nov., a novel aerobic, facultatively autotrophic and methylotrophic bacterium that utilizes dichloromethane
}

\footnotetext{
1 Institute of Biochemistry and Physiology of Microorganisms, Russian Academy of Sciences, Pushchino, Moscow Region, 142290, Russia

2,3 Institute of Microbiology2 and Centre

'Bioengineering' 3 , Russian Academy of Sciences, Moscow 117811, Russia

4 Institut für Mikrobiologie, Eidgenössische Technische Hochschule, ETH-Zentrum, CH-8092

Zürich, Switzerland
}

\author{
Nina V. Doronina, ${ }^{1}$ Yuri A. Trotsenko, ${ }^{1}$ Tatjana P. Tourova, ${ }^{2}$ \\ Boris B. Kuznetsov ${ }^{3}$ and Thomas Leisinger ${ }^{4}$ \\ Author for correspondence: Yuri A. Trotsenko. Tel: +7 095925 7448. Fax: +7 0959563370. \\ e-mail: trotsenko@ibpm.serpukhov.su
}

\begin{abstract}
A novel genus, Albibacter, with one species, Albibacter methylovorans sp. nov., is proposed for a facultatively chemolithotrophic and methylotrophic bacterium (strain DM10') with the ribulose bisphosphate (RuBP) pathway of $C_{1}$ assimilation. The bacterium is a Gram-negative, aerobic, asporogenous, nonmotile, colourless rod that multiplies by binary fission. The organism utilizes dichloromethane, methanol, methylamine, formate and $\mathrm{CO}_{2} / \mathrm{H}_{2}$, as well as a variety of polycarbon compounds, as carbon and energy sources. It is neutrophilic and mesophilic. The major cellular fatty acids are straight-chain unsaturated $C_{18: 1}$, saturated $C_{16: 0}$ and cyclopropane $C_{19: 0}$ acids. The main ubiquinone is Q-10. The dominant phospholipids are phosphatidyl ethanolamine, phosphatidyl glycerol, phosphatidyl choline and cardiolipin. The DNA G+C content is $66.7 \mathrm{~mol} \%$. Strain DM10' has a very low degree of DNA-DNA hybridization (4-7\%) with the type species of the genera Paracoccus, Xanthobacter, Blastobacter, Angulomicrobium, Ancylobacter and Ralstonia of RuBP pathway methylobacteria. Another approach, involving comparative 165 rDNA analysis, has shown that the novel isolate represents a separate branch within the $\alpha-2$ subgroup of the Proteobacteria. The type species of the new genus is Albibacter methylovorans sp. nov.; the type strain is DM10 (= VKM $B^{-2236}{ }^{\top}=$ DSM 13819')
\end{abstract}

Keywords: Albibacter, ribulose bisphosphate pathway, methylotroph

\section{INTRODUCTION}

Dichloromethane (DCM), or methylene chloride, is a widely used industrial solvent that escapes at a considerable rate into the environment. Both aerobic methylotrophic bacteria (Leisinger et al., 1994) and a strictly anaerobic acetogenic bacterium (Mägli et al., 1998) growing with DCM as the sole carbon and energy source have been isolated. A set of 14 aerobic DCM-utilizing bacteria (strains DM1-DM14) has previously been isolated from soils and waters contaminated with the compound (Brunner et al., 1980; Stucki et al., 1981; Gaelli \& Leisinger, 1985; Scholtz et

Abbreviations: DCM, dichloromethane; GSH, reduced glutathione; PMS, phenazine methosulfate; RuBP, ribulose bisphosphate.

The GenBank accession number for the 16S rDNA sequence of Albibacter methylovorans DM10 ${ }^{\top}$ is AF 273213. al., 1988). In all of these strains, the initial step of DCM utilization is catalysed by a glutathione-dependent DCM dehalogenase. This enzyme transforms DCM plus one molecule of water to formaldehyde and two molecules of hydrochloric acid. The overall reaction is thought to involve the enzyme-catalysed dehalogenative formation of an $S$-chloromethyl glutathione conjugate, which subsequently undergoes hydrolysis to formaldehyde, glutathione and hydrochloric acid (Leisinger et al., 1994). Extensive phenotypic and genotypic characterization of the 14 aerobic DCM utilizers has led to the classification of seven representatives (strains DM1, DM3 and DM5-DM99 ${ }^{\mathrm{T}}$ ) as Methylopila helvetica (Doronina et al., 2000). Four further representatives were classified as Methylobacterium dichloromethanicum $\mathrm{DM} 4^{\mathrm{T}}$ (Doronina et al., 2000), Methylorhabdus multivorans DM13 ${ }^{\mathrm{T}}$ (Doronina et al., 1995), Methylophilus leisingeri DM11 ${ }^{\mathrm{T}}$ 
(Doronina \& Trotsenko, 1994) and Paracoccus methylutens $\mathrm{DM} 12^{\mathrm{T}}$ (Doronina et al., 1998a). Like the latter organism, one of the remaining unidentified isolates (strain DM10 $0^{\mathrm{T}}$ ) had the ribulose bisphosphate (RuBP) pathway for $\mathrm{C}_{1}$ assimilation (Doronina et al., 1992), but differed from known facultatively autotrophic methylotrophic bacteria in some other properties.

The group of aerobic Gram-negative, asporogenous, facultatively autotrophic and methylotrophic bacteria having the RuBP pathway and capable of growth on a variety of reduced $C_{1}$ substrates, except methane, is very heterogeneous and includes the genera Paracoccus, Xanthobacter, Blastobacter, Angulomicrobium, Ralstonia and Ancylobacter. The representatives of Xanthobacter form pleomorphic cells, which are slimy and yellow due to the water-insoluble carotenoid pigment zeaxanthin dirhamnozide (Wiegel, 1992; Urakami et al., 1995). Species of the genera Blastobacter (irregular ovoid pleomorphic rods) (Sly, 1985; Trotsenko et al., 1989) and Angulomicrobium (tetrahedron-shaped cells) (Vasilyeva et al., 1979; Vasilyeva, 1989) multiply by budding. The vibrioid cells of the genus Ancylobacter (Raj, 1981, 1983) have a characteristic morphology and rings that are formed occasionally prior to cell division. Ralstonia (formerly Alcaligenes) species are motile by one to eight peritrichous flagella (Kersters \& De Ley, 1984). This report presents the results of our polyphasic taxonomy studies, indicating that strain DM $10^{\mathrm{T}}$ should be placed in a novel genus, for which the name Albibacter gen. nov. is proposed; the genus has a single species, Albibacter methylovorans sp. nov.

\section{METHODS}

Bacterial strains. Strain DM10 ${ }^{\mathrm{T}}$ was isolated on DCM agar from a ground-water sample by a procedure described previously (Gaelli \& Leisinger, 1985). The organisms used for comparative studies included the following reference strains of aerobic, facultatively autotrophic and methylotrophic bacteria: Paracoccus denitrificans ATCC 17441 ${ }^{\mathrm{T}}$, Paracoccus methylutens VKM B-2164 ${ }^{\mathrm{T}}$, Paracoccus aminovorans JCM $7685^{\mathrm{T}}$, Paracoccus aminophilus JCM $7686^{\mathrm{T}}$, Xanthobacter autotrophicus DSM 432 ${ }^{\mathrm{T}}$, Blastobacter denitrificans IFAM 1005 ${ }^{\mathrm{T}}$, Angulomicrobium tetraedrale Z-2821 ${ }^{\mathrm{T}}$ ( = VKM B-1335 $)$, Ancylobacter aquaticus ATCC $25396^{\mathrm{T}}$, Ralstonia eutropha H16 DSM 428 and Methylopila capsulata VKM B-1606 ${ }^{\mathrm{T}}$. They were maintained on PYG agar medium, which contained $0.5 \%$ peptone, $0.5 \%$ yeast extract, $0.5 \%$ glucose and $2 \%$ Difco Bacto agar ( $\mathrm{pH} 7 \cdot 0)$. Strain DM10 $0^{\mathrm{T}}$ was grown on minimal medium $\mathrm{K}$, which contained $\left(\mathrm{g} \mathrm{l}^{-1}\right): \mathrm{KH}_{2} \mathrm{PO}_{4}, 2 \cdot 0 ;\left(\mathrm{NH}_{4}\right)_{2} \mathrm{SO}_{4}, 2 \cdot 0 ; \mathrm{MgSO}_{4} .7 \mathrm{H}_{2} \mathrm{O}, 0 \cdot 025$; $\mathrm{NaCl}, 0 \cdot 5$. Prior to autoclaving, the $\mathrm{pH}$ of the medium was adjusted to $7 \cdot 2$. After sterilization, an appropriate carbon source and $0.02 \%(\mathrm{v} / \mathrm{v})$ yeast autolysate were added and 11 medium was supplemented with $1 \mathrm{ml}$ trace element solution (Doronina et al., 1995). Methanol or methylamine was added to a concentration of 0.5 or $0.3 \%(\mathrm{v} / \mathrm{v})$, respectively. Unless otherwise mentioned, the bacteria were grown at $29^{\circ} \mathrm{C}$ in $750 \mathrm{ml}$ Erlenmeyer flasks containing $200 \mathrm{ml}$ medium on a rotary shaker at 180 r.p.m. During cultivation with DCM, the flasks were closed tightly with rubber stoppers.
Since the $\mathrm{pH}$ of the medium decreased when DCM was consumed, the compound was added in three portions to a final concentration of $10 \mathrm{mM}\left(0.65 \mathrm{gl}^{-1}\right)$, each after the $\mathrm{pH}$ of the medium had been adjusted to $7 \cdot 2$ with $\mathrm{NaOH}$. Other sterile carbon sources were added from filter-sterilized stock solutions. The concentrations of the tested carbon sources ranged between 0.5 and $3.0 \mathrm{~g} \mathrm{l}^{-1}$. For growth on agarsolidified medium with DCM, Petri dishes were incubated in a desiccator, $0.1 \mathrm{ml}$ portions of DCM being added to a reagent tube three times, each after $48 \mathrm{~h}$. The bacterial strains were maintained on liquid minimal medium $\mathrm{K}$ for $10 \mathrm{~d}$ on agar-solidified slants with an appropriate $\mathrm{C}_{1}$ substrate at $4{ }^{\circ} \mathrm{C}$ for 2 weeks and in the freeze-dried state with a protectant (skimmed milk) for over a year.

Identification methods. If not otherwise indicated, the methods, reagents and media used for phenotypic characterization were as described by Smibert \& Krieg (1994). Cell morphology, Gram staining, motility and flagellation were determined by using cultures grown on PYG agar. Production of a fluorescent pigment was tested on King A and $\mathrm{B}$ agar-solidified media. Nitrate reduction was tested in liquid medium $\mathrm{K}$, in which $\left(\mathrm{NH}_{4}\right)_{2} \mathrm{SO}_{4}$ was replaced by $0.5 \%$ $(\mathrm{w} / \mathrm{v}) \mathrm{KNO}_{3}$, after 1,3 and $5 \mathrm{~d}$ incubation. The methyl red and Voges-Proskauer (acetoin) reactions were tested in glucose/phosphate/peptone broth. Indole production was determined by the Salkowski reagent (Gordon \& Weber, 1951 ) in medium $\mathrm{K}$ with $0.5 \%$ methanol and $1 \%$ tryptophan. Hydrogen sulfide production was tested on triplesugar-iron agar for 2 weeks. Gelatin hydrolysis was observed in stab cultures in yeast extract/peptone medium containing $12 \%$ gelatin after 4 weeks incubation at $22^{\circ} \mathrm{C}$. Starch hydrolysis was determined by using an iodine solution on agar-solidified medium $\mathrm{K}$ containing $0 \cdot 2 \%$ soluble starch after 1,3 and $10 \mathrm{~d}$ incubation.

Ammonia production was tested in peptone water by using Nessler's reagent. The oxidase activity test was performed with a $1 \%$ solution of tetramethyl- $p$-phenylenediamine dihydrochloride. Urease activity was observed on Christensen's medium. Catalase activity was detected by pouring a $3 \% \mathrm{H}_{2} \mathrm{O}_{2}$ solution into colonies on solid medium $\mathrm{K}$ or PYG agar. Halotolerance was tested by inoculating the cells into liquid medium $\mathrm{K}$ with various concentrations of $\mathrm{NaCl}(1-14 \%)$. Growth at different temperatures and $\mathrm{pH}$ values was tested in liquid medium $\mathrm{K}$ with $0.5 \%(\mathrm{v} / \mathrm{v})$ methanol. Utilization of a wide range of growth substrates $(>50)$ was also determined in liquid medium $\mathrm{K}$ after 2 weeks cultivation, with methanol being replaced by the other carbon compounds. Organic acids and amino acids were added at concentrations of $0 \cdot 05-0 \cdot 30 \%$, whereas carbohydrates and alcohols were added at concentrations of $0 \cdot 2-0 \cdot 5 \%$.

Methane utilization was tested in an atmosphere containing methane and air $(1: 1, \mathrm{v} / \mathrm{v})$ in $700 \mathrm{ml}$ conical flasks containing $100 \mathrm{ml}$ medium $\mathrm{K}$ and fitted with rubber stoppers. Hydrogen utilization was tested by the same procedure, but in an atmosphere of $\mathrm{H}_{2} / \mathrm{O}_{2} / \mathrm{CO}_{2}(7: 2: 1$, by vol.). Utilization of chloromethane was tested as described for DCM (Doronina et al., 1995). To test alternative nitrogen sources, $\left(\mathrm{NH}_{4}\right)_{2} \mathrm{SO}_{4}$ was replaced by other nitrogen compounds.

Enzyme assays were done as described previously (Trotsenko et al., 1986; Doronina et al., 1995). Cellular phospholipids, ubiquinones and fatty acids were analysed according to methods described previously (Doronina et al., 1998a, b).

Electron-microscope analysis. A cell suspension was mounted 
on a Formvar-coated copper grid and stained with $0.2 \%$ $(\mathrm{w} / \mathrm{v})$ phosphotungstic acid $(\mathrm{pH} 7 \cdot 2)$. For thin sectioning, samples were prefixed with $1.5 \%(\mathrm{v} / \mathrm{v})$ glutaraldehyde in $0.05 \mathrm{M}$ cacodylate buffer $(\mathrm{pH} 7 \cdot 2)$ and washed three times with $1 \%(\mathrm{w} / \mathrm{v}) \mathrm{OsO}_{4}$ in $0.05 \mathrm{M}$ cacodylate buffer (pH 7.2) for $3 \mathrm{~h}$ at $20^{\circ} \mathrm{C}$. After dehydration in an alcohol series, the cells were embedded in Spurr epoxy resin and sectioned with an LKB 2128 Ultratome. The ultrathin sections were mounted on copper grids and double-stained with uranyl acetate and lead citrate. Negatively stained preparations and thin sections were imaged in a JEOL JEM100B transmission electron microscope at an operating voltage of $60 \mathrm{kV}$.

DNA isolation and characterization. DNA was isolated and purified according to Marmur (1961). Its G+C content was determined by the thermal denaturation $\left(T_{\mathrm{m}}\right)$ method with a Beckman DU-8B spectrophotometer at a heating rate of $0.5^{\circ} \mathrm{C} \mathrm{min}^{-1}$ and calculated according to Owen \& Lapage (1976). DNA from Escherichia coli K-12 was used as a standard. DNA-DNA hybridizations were done on nitrocellulose membrane filters $(0.22 \mu \mathrm{m})$ according to the procedure of Denhardt (1966) in the following incubation mixture: $0.15 \mathrm{M} \mathrm{NaCl}$ and $0.015 \mathrm{M}$ trisodium citrate, $\mathrm{pH}$ $7 \cdot 0$, with $30 \%$ formamide at $60^{\circ} \mathrm{C}$ for $24 \mathrm{~h}$. Deoxy[1', $2^{\prime}, 5^{\prime}-$ $\left.{ }^{3} \mathrm{H}\right] \mathrm{CTP}$ and the nick translation kit N 5500 (Amersham) were used to label the DNA probes.

16S rDNA amplification and sequencing. Genomic DNA was isolated by standard phenol/chloroform extraction. The $16 \mathrm{~S}$ rRNA gene was selectively amplified by PCR using the following primers: forward primer, 5'-AGAGTTTGATCCTGGCTCAG-3' (8-27 by E. coli numbering); reverse primer, 5'-TACGGTTACCTTGTTACGACTT-3' (14711492 by $E$. coli numbering) (Lane, 1991). The PCR was carried out in a final volume of $100 \mu \mathrm{l}$, with $1 \mu \mathrm{g}$ DNA template, $200 \mu \mathrm{M}$ each primer, $200 \mu \mathrm{M}$ each dNTP, 3 U Tet$\mathrm{z}$ polymerase (BioMaster) and reaction buffer $(100 \mathrm{mM}$ Tris/ $\left.\mathrm{HCl}, \mathrm{pH} 8 \cdot 3,500 \mathrm{mM} \mathrm{KCl}, 2 \mathrm{mM} \mathrm{MgCl}_{2}\right)$. The temperature cycling was done by using 30 cycles of the following thermal profile: $1 \mathrm{~min}$ at $94{ }^{\circ} \mathrm{C}, 1 \mathrm{~min}$ at $42{ }^{\circ} \mathrm{C}$ and $1 \mathrm{~min}$ at $72^{\circ} \mathrm{C}$. The final extension was carried out at $72^{\circ} \mathrm{C}$ for 6 min. The PCR products were purified using the PCRprep kit (Promega) according to the manufacturer's instructions. DNA sequencing was carried out by using the Sequenase version 2 kit (USB) with minor modifications.

Phylogenetic analysis. The $16 \mathrm{~S}$ rDNA sequence of strain $\mathrm{DM}^{\mathrm{T}}$ was manually aligned to representative proteobacterial sequences obtained from the GenBank database. Regions that were not sequenced in one or more reference organisms were omitted from the final analysis and $1236 \mathrm{nt}$ in total were used for tree construction. Pairwise evolutionary distances (expressed as estimated changes per $100 \mathrm{nt}$ ) were computed by use of the correction of Jukes \& Cantor (1969). The unrooted phylogenetic tree was constructed by the neighbour-joining method (Saitou \& Nei, 1987) with bootstrap analysis of 100 trees and by using the programs of the TREECON package (Van de Peer \& De Wachter, 1994).

\section{RESULTS}

\section{Morphology}

Strain DM10 ${ }^{\mathrm{T}}$ was a Gram-negative, non-motile short rod, $0.9-1.0 \times 1.2-1.8 \mu \mathrm{m}$ in size, with a cell shape that sometimes approached coccoid (Fig. 1a, b). It did not form flagella, endospores or prosthecae. Cells occurred

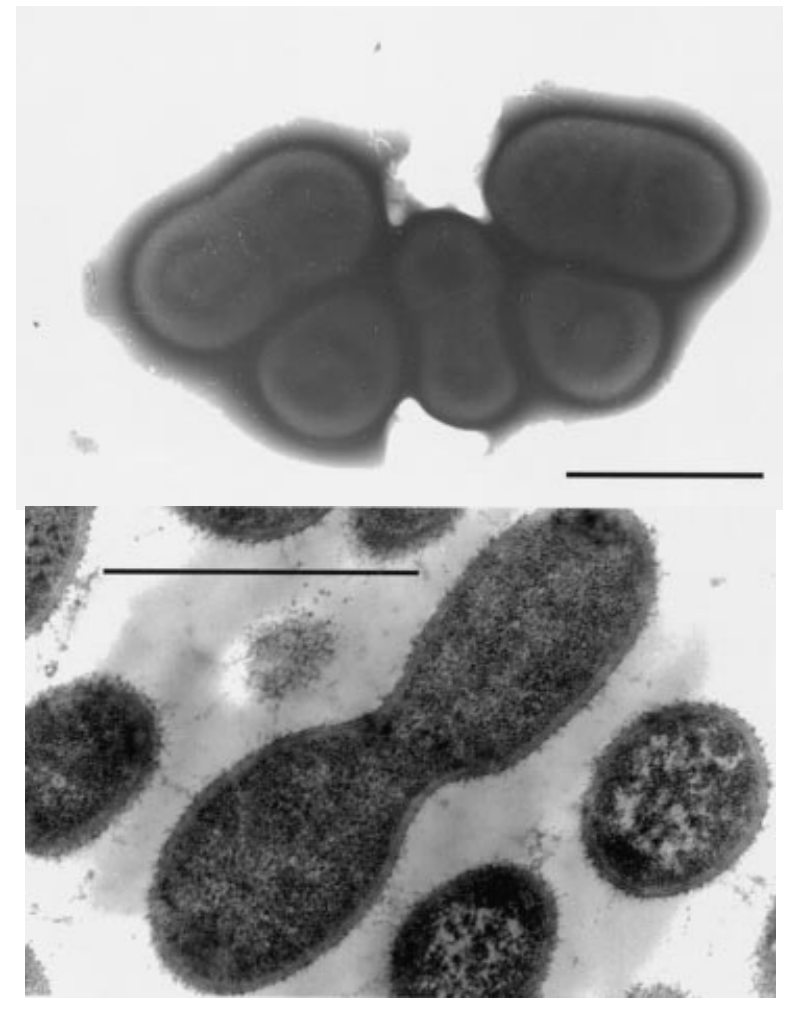

Fig. 1. Electron micrographs of cells of strain $\mathrm{DM} 10^{\top}$. Upper micrograph, negatively stained preparation; lower micrograph, ultrathin section showing cell wall structure. Bars, $1 \mu \mathrm{m}$.

singly or in pairs and sometimes in clusters. Reproduction was by binary fission. Special subcellular structures related to the autotrophic or methylotrophic modes of life, such as carboxysomes or intracytoplasmic membranes, were not observed.

\section{Phenotypic characteristics}

Colonies on PYG agar (3 d) were punctate, round, convex, lustrous, white, transparent, uniform in consistency and mucoid. Streak cultures on meat/peptone agar were distinct and white, with even edges, a smooth surface and a mucoid consistency. Growth was moderate and odourless. No water-soluble fluorescent pigment was produced. Nitrate was reduced to nitrite. Isolate DM10 $10^{\mathrm{T}}$ hydrolysed starch (weakly), but not gelatin, cellulose or casein milk. It formed indole from tryptophan on medium with nitrate as a nitrogen source. Methyl red and Voges-Proskauer tests were negative. Urease and catalase were present, but oxidase activity was very low.

Strain DM10 $0^{\mathrm{T}}$ grew well on mineral salt liquid medium with a gas mixture of $\mathrm{CO}_{2} / \mathrm{H}_{2} / \mathrm{O}_{2}$, DCM (optimal concentration $0 \cdot 05-0 \cdot 1 \%, \mathrm{v} / \mathrm{v})$, methanol $(0 \cdot 5 \%, \mathrm{v} / \mathrm{v})$, methylamine $(0.3 \%, \mathrm{w} / \mathrm{v})$ or formate $(0.05 \%, \mathrm{w} / \mathrm{v})$ as the carbon and energy sources. Growth on $\mathrm{C}_{1}$ substrates was stimulated by addition of yeast autolysate $(0.01 \%)$ or thiamin/biotin (both at $\left.20 \mu \mathrm{g} \mathrm{l}^{-1}\right)$. Growth was also supported by glucose, fructose, arabinose, 
Table 1. Cellular fatty acid composition of strain $\mathrm{DM} 10^{\top}$ grown on PYG agar (48 h)

\begin{tabular}{|lc|}
\hline Fatty acid & Percentage of total fatty acids \\
\hline Iso $15: 0$ & $0 \cdot 3$ \\
Anteiso $15: 0$ & $1 \cdot 5$ \\
Iso $16: 0$ & $0 \cdot 7$ \\
$16: 1$ & $1 \cdot 5$ \\
$16: 0$ & $19 \cdot 7$ \\
Anteiso $17: 0$ & $1 \cdot 0$ \\
Unsaturated 18 & $11 \cdot 6$ \\
$c 18: 1 \omega 7$ & $57 \cdot 6$ \\
$18: 0$ & $6 \cdot 0$ \\
\hline
\end{tabular}

maltose, mannose, sorbose, ribose, sucrose, sorbitol, mannitol, glycerol, inositol, dulcitol, adonitol, ethanol, acetate, 2-oxoglutarate, fumarate, pyruvate, succinate, malate, propionate, acetamide, L-glutamate or $\mathrm{L}$ alanine. A gas mixture of $\mathrm{CH}_{4} / \mathrm{CO}_{2} / \mathrm{O}_{2}$ as well as formaldehyde, di- and trimethylamine, chloromethane, thiocyanate, thiosulfate, dimethyl acetamide and DMSO did not support growth. Strain DM10 utilized methylamine, some amino acids, urea, peptone, ammonium salts and nitrates as nitrogen sources.

Good growth occurred between $\mathrm{pH} 6.0$ and $9 \cdot 0$, but not above $\mathrm{pH} 9.5$ or below $\mathrm{pH} 6 \cdot 0$. The optimum growth temperature was $28-30{ }^{\circ} \mathrm{C}$ and the $\mathrm{pH}$ optimum was 7.5-8.0. Growth did not occur in the presence of $3 \% \mathrm{NaCl}$. The generation time was $0.08 \mathrm{~h}^{-1}$ on medium K with $10 \mathrm{mM}$ DCM. Strain $\mathrm{DM}^{1} 0^{\mathrm{T}}$ grew as an aerobic facultative chemolithotroph with a respiratory type of metabolism using oxygen as the terminal electron acceptor. No anaerobic growth was observed in the presence of potassium nitrate. The organism was resistant to penicillin and rifampicin, but sensitive to gentamicin, kanamycin, ampicillin, neomycin, novobiocin, nalidixic acid, tetracycline and lincomycin (all at $30 \mu \mathrm{g} \mathrm{ml}^{-1}$ ).

\section{Chemotaxonomic characteristics}

As shown in Table 1, the dominant cellular fatty acids of strain $\mathrm{DM} 10^{\mathrm{T}}$ were cis-vaccenic $(c 18: 1 \omega 7)$ and palmitic (16:0) acids. Analysis of the cellular phospho-

Table 2. Enzyme activities in cell extracts of the strain DM10 $10^{\top}$ grown with DCM or methylamine

No activity of any of the following enzymes was observed (cofactors in parentheses):

formaldehyde dehydrogenase (PMS), formate dehydrogenase $\left(\mathrm{NAD}^{+}\right)$, hydroxypyruvate reductase $(\mathrm{NADH})$, serine-glyoxylate aminotransferase $[\mathrm{NAD}(\mathrm{P}) \mathrm{H}]$, malate lyase $(\mathrm{ATP}, \mathrm{CoA})$, 3-hexulose-phosphate synthase, 2-keto-3-deoxy-6-phosphogluconate aldolase and glutamate dehydrogenase (NADH).

\begin{tabular}{|c|c|c|}
\hline \multirow[t]{2}{*}{ Enzyme (co-substrates) } & \multicolumn{2}{|c|}{ Enzyme activity $\left[\mathrm{nmol} \min ^{-1}(\mathrm{mg} \text { protein })^{-1}\right]$} \\
\hline & DCM-grown cells & Methylamine-grown cells \\
\hline DCM dehalogenase (GSH) & 118 & 0 \\
\hline Methylamine dehydrogenase (PMS) & 0 & 120 \\
\hline Formaldehyde dehydrogenase $\left(\mathrm{NAD}^{+}, \mathrm{GSH}\right)$ & 700 & 620 \\
\hline Formate dehydrogenase (PMS) & 50 & 20 \\
\hline Hydroxypyruvate reductase (NADPH) & 120 & 116 \\
\hline Phosphoribulokinase & 70 & 92 \\
\hline Ribulose-1,5-bisphosphate carboxylase & 120 & 145 \\
\hline Glucose-6-phosphate dehydrogenase $\left(\mathrm{NAD}^{+}\right)$ & 60 & 67 \\
\hline Glucose-6-phosphate dehydrogenase $\left(\mathrm{NADP}^{+}\right)$ & 60 & 70 \\
\hline 6-Phosphogluconate dehydrogenase $\left(\mathrm{NAD}^{+}\right)$ & 64 & 69 \\
\hline 6-Phosphogluconate dehydrogenase $\left(\mathrm{NADP}^{+}\right)$ & 64 & 65 \\
\hline Fructose-1,6-bisphosphate aldolase & 30 & 44 \\
\hline Pyruvate dehydrogenase $\left(\mathrm{NAD}^{+}\right)$ & 17 & 21 \\
\hline Citrate synthase & 27 & 35 \\
\hline Isocitrate dehydrogenase $\left(\mathrm{NAD}^{+}\right)$ & 22 & 18 \\
\hline Isocitrate dehydrogenase $\left(\mathrm{NADP}^{+}\right)$ & 362 & 380 \\
\hline$\alpha$-Ketoglutarate dehydrogenase $\left(\mathrm{NAD}^{+}\right)$ & 26 & 28 \\
\hline Isocitrate lyase & 12 & 15 \\
\hline Malate synthase & 16 & 17 \\
\hline Glutamate dehydrogenase (NADPH) & 75 & 81 \\
\hline Glutamate synthase (NADPH) & 21 & 24 \\
\hline Glutamine synthetase (ADP, $\mathrm{Mn}^{2+}$ ) & 30 & 37 \\
\hline
\end{tabular}




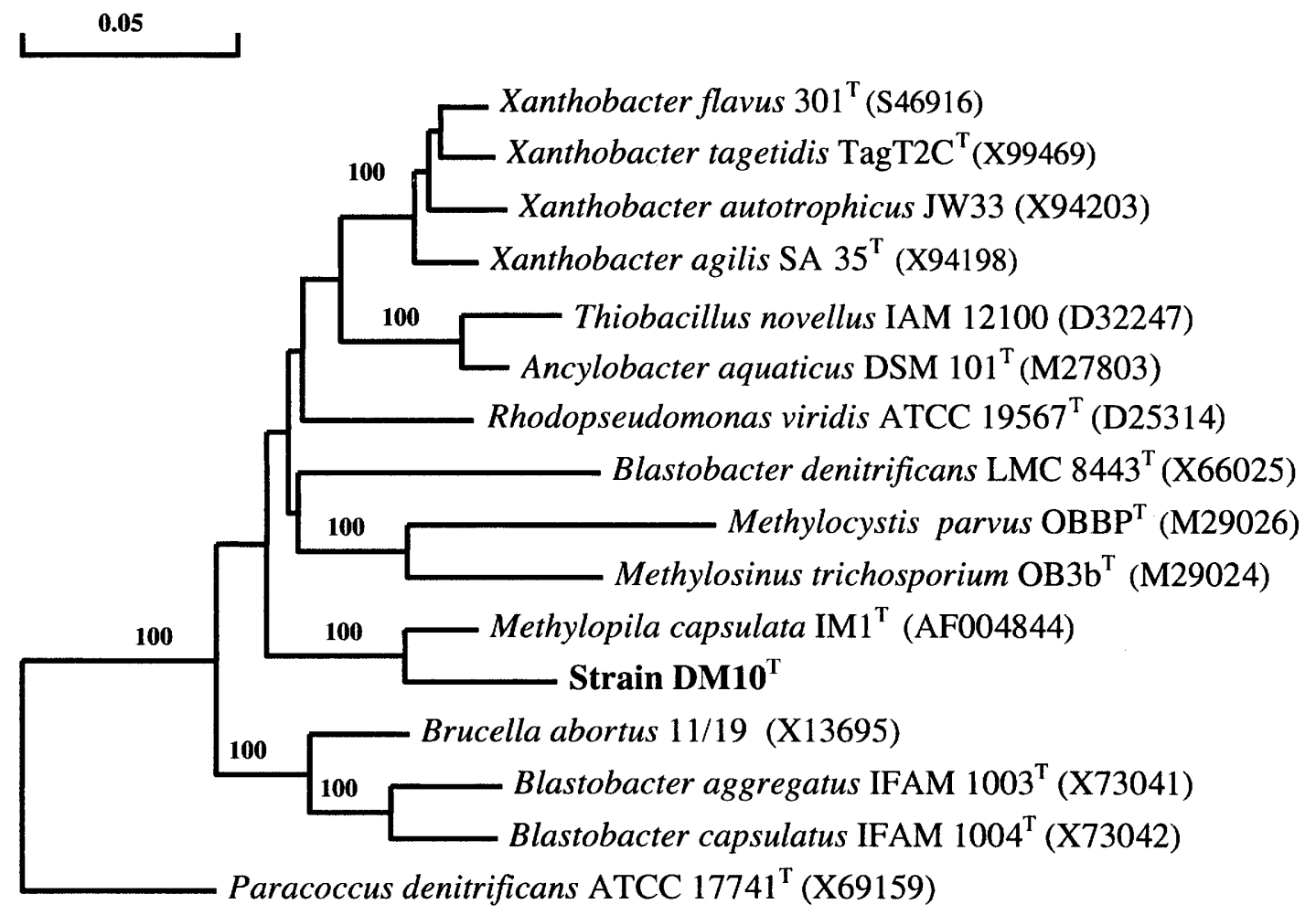

Fig. 2. Unrooted phylogenetic tree showing relationships between Albibacter methylovorans $\mathrm{DM} 10^{\top}$ and other members of the $\alpha$-Proteobacteria, including methylotrophic genera. The 16S rDNA sequence obtained in this study is shown in bold. Bootstrap values (expressed as percentages of 100 replications) are shown at the appropriate branch points. Bar, Jukes \& Cantor evolutionary distance.

lipids revealed the presence of phosphatidyl ethanolamine, phosphatidyl glycerol, cardiolipin, phosphatidyl choline, phosphoserine, lysolecithin and a minor unidentified phospholipid. The major ubiquinone is $\mathrm{Q}-10$.

\section{Metabolic characteristics}

In order to establish the routes of primary and intermediary $\mathrm{C}_{1}$ metabolism in strain $\mathrm{DM} 10^{\mathrm{T}}$, enzyme activities were determined in extracts of cells grown on DCM or methylamine. As shown in Table 2, DCMgrown cells contained an inducible, reduced glutathione (GSH)-dependent DCM dehalogenase, whereas methylamine-grown cells possessed methylamine dehydrogenase. Formaldehyde was further oxidized by GSH-dependent formaldehyde dehydrogenase to formate. The latter was finally oxidized to $\mathrm{CO}_{2}$ by phenazine methosulfate (PMS)-linked formate dehydrogenase. Carbon dioxide was assimilated via the RuBP pathway (Benson-Calvin cycle), as confirmed by the presence of phosphoribulokinase and ribulose-1,5-bisphosphate carboxylase. Neither the serine nor the ribulose monophosphate pathway of $\mathrm{C}_{1}$ assimilation was operative, due to the absence of the appropriate specific enzymes: hydroxypyruvate reductase (NADH), serine-glyoxylate aminotransferase, malate lyase and hexulose-phosphate synthase. Strain
DM10 ${ }^{\mathrm{T}}$ had no 2-keto-3-deoxy-6-phosphogluconate aldolase; therefore the Entner-Doudoroff pathway did not function. In addition, the enzymes of the pentose phosphate pathway (glucose-6-phosphate and 6-phosphogluconate dehydrogenases) were present at low levels. Hence, fructose-1,6-bisphosphate aldolase might play an important role in the glycolytic conversion of phosphohexoses and phosphotrioses. Strain $\mathrm{DM} 10^{\mathrm{T}}$ contained pyruvate dehydrogenase as well as a complete set of the tricarboxylic acid cycle and glyoxylate shunt enzymes. Primary assimilation of ammonia occurred by both reductive amination of 2oxoglutarate and through the glutamate cycle (the GS/GOGAT system).

\section{Genomic characteristics}

The $\mathrm{G}+\mathrm{C}$ content of DNA of strain $\mathrm{DM} 10^{\mathrm{T}}$ was $66.7 \mathrm{~mol} \%$ ( $T_{\mathrm{m}}$ method). To estimate the extent of DNA similarity of this strain with DNAs from representatives of other bacterial taxa, the filter hybridization method was used. Strain DM $10^{\mathrm{T}}$ showed low levels of DNA-DNA relatedness $(2-7 \%)$ to the following strains: $P$. denitrificans ATCC $17441^{\mathrm{T}}, P$. methylutens VKM B-2164 ${ }^{\mathrm{T}}, P$. aminovorans JCM $7686^{\mathrm{T}}$, P. aminophilus JCM $7686^{\mathrm{T}}$, Xanthobacter autotrophicus DSM 432 ${ }^{\mathrm{T}}$, Blastobacter denitrificans IFAM $1005^{\mathrm{T}}$, Blastobacter capsulatus IFAM 1004 ${ }^{\mathrm{T}}$, Angulo- 
microbium tetraedrale Z-2821 ${ }^{\mathrm{T}}$, Ancylobacter aquaticus ATCC 25396 ${ }^{\mathrm{T}}$, Ralstonia eutropha DSM 428 and Methylopila capsulata VKM B-1606 ${ }^{\mathrm{T}}$.

\section{Comparative 16S rDNA sequence analysis}

A total of $1409 \mathrm{nt}$ of the $16 \mathrm{~S}$ rDNA sequence was determined for strain $\mathrm{DM} 10^{\mathrm{T}}$, corresponding to positions 19-1482 of the E. coli sequence. The sequence was compared with the appropriate sequences of some representatives of the $\alpha$-Proteobacteria, including RuBP-pathway methylobacteria belonging to the genera Paracoccus, Xanthobacter, Blastobacter and Ancylobacter. Surprisingly, the matrix of full sequence similarity values for strain $\mathrm{DM} 10^{\mathrm{T}}$ and representative members of the Proteobacteria indicated a rather high identity $(95.4 \%)$ to a recently described member of the $\alpha-2$ subgroup, Methylopila capsulata (Doronina et al., 1998b). The degree of sequence similarity to the other members of the $\alpha-2$ subgroup was significantly lower $(86 \cdot 3-90 \cdot 5 \%)$. The lowest level of similarity $(86 \cdot 0 \%)$ was found to $P$. denitrificans, a member of the $\alpha-3$ subgroup. As seen in Fig. 2, strain DM10 $10^{\mathrm{T}}$ formed a single cluster with the type strain of the serine-pathway methylotroph Methylopila capsulata (bootstrap value of $100 \%$ ). However, the scale of evolutionary changes in the $16 \mathrm{~S}$ rRNA gene of strain DM10 ${ }^{\mathrm{T}}$ in comparison with that of the related $\alpha$-2 subgroup of the Proteobacteria did not correspond to profound (essential) changes in the phenotype of the bacterium. Hence, considering sequence homology as part of a polyphasic taxonomy approach to classification and identification of these methylotrophs, further genotypic and phenotypic information must also be taken into account (Vandamme et al., 1996). In this context, a very low degree of DNA-DNA hybridization $(<5 \%)$ and some essential chemotaxonomic and biochemical differences, particularly the operation of the RuBP pathway in strain $\mathrm{DM} 10^{\mathrm{T}}$, argue strongly against its formal generic clustering with Methylopila capsulata.

\section{DISCUSSION}

Six generic names have been validly published for Gram-negative RuBP-pathway methylobacteria: Paracoccus, Xanthobacter, Blastobacter, Angulomicrobium, Ancylobacter and Ralstonia (formerly Alcaligenes). Our isolate differed from the members of these genera in some essential phenotypic and genotypic characteristics. Phylogenetic analysis confirmed the absence of close relatedness between strain DM10 ${ }^{\mathrm{T}}$ and species of the genera Xanthobacter and Blastobacter. Although strain DM10 $0^{\mathrm{T}}$ resembled Paracoccus species on the basis of morphology, ubiquinone system, pathway of $C_{1}$ assimilation and range of DNA $\mathrm{G}+\mathrm{C}$ content, it had very low DNA-DNA similarities $(5-7 \%)$ to the type species of this genus and thus belongs to another subgroup of the Proteobacteria. Despite rather high $16 \mathrm{~S}$ rDNA similarity to the type strain of Methylopila capsulata, strain $\mathrm{DM} 10^{\mathrm{T}}$ was clearly distinct from this serine-pathway methylotroph in some morphological features, cellular phospholipids and fatty acids, autotrophic growth and operation of the RuBP pathway, as well as by virtue of a very low DNA-DNA hybridization value. Based on these results and adopting a polyphasic approach to taxonomy (Vandamme et al., 1996), strain DM10 ${ }^{\mathrm{T}}$ should be placed in a separate taxon, the genus Albibacter gen. nov. Phylogenetic relationships that were derived from the 16S rDNA sequence analysis showed that the new genus formed a distinct branch within the $\alpha-2$ subgroup of the Proteobacteria. The genus Albibacter contains a single species, which is automatically the type species of the genus, and it is therefore proposed that the new species be named Albibacter methylovorans sp. nov.

\section{Description of Albibacter gen. nov.}

Albibacter (Al.bi.bac'ter. L. adj. albus white; M.L. masc. n. bacter equivalent of Gr. neut. n. baktron a small rod; M.L. masc. n. Albibacter white rod).

Cells are Gram-negative, non-sporulating, colourless rods that occur singly, in pairs or in clusters and multiply by binary fission. Colonies on methanol or PYG agar are circular, 1-2 $\mathrm{mm}$ in diameter, white, convex, translucent to opaque and mucoid. Methyl red and Voges-Proskauer tests are negative. Does not produce water-soluble fluorescent pigment. Indole is produced from tryptophan on medium with nitrate as nitrogen source. Reduces nitrate to nitrite. No anaerobic growth in the presence of nitrate. Produces acids from sugars oxidatively, but not fermentatively. Hydrolyses starch, but not gelatin or cellulose. Chemolithoheterotrophic and facultatively methylotrophic, assimilating $\mathrm{C}_{1}$ compounds by the RuBP pathway. Able to grow on a wide spectrum of polycarbon substrates. Ammonium salts, nitrate, urea, peptone, some amino acids and methylamine are utilized as nitrogen sources. Strictly aerobic, with a respiratory type of metabolism. Neutrophilic and mesophilic. Grows at $\mathrm{pH} 6 \cdot 0-9 \cdot 0$ and at temperatures between 10 and $37^{\circ} \mathrm{C}$. No growth in the presence of $3 \% \mathrm{NaCl}$. The major ubiquinone is Q-10. Dominant phospholipids are phosphatidyl ethanolamine, phosphatidyl glycerol, phosphatidyl choline and phosphoserine. The prevailing cellular fatty acids are cis-vaccenic

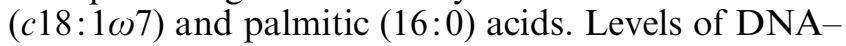
DNA hybridization with representatives of the genera Paracoccus, Xanthobacter, Blastobacter, Angulomicrobium, Ralstonia and Methylopila are less than $7 \%$. The genus Albibacter belongs to the $\alpha-2$ subgroup of the Proteobacteria, as revealed by comparative sequence analysis of the $16 \mathrm{~S}$ rDNA. The type species is Albibacter methylovorans.

\section{Description of Albibacter methylovorans sp. nov.}

Albibacter methylovorans (me.thy.lo.vor'ans. M.L. n. methylum the methyl group; L. part adj. vorans devouring, digesting; methylovorans digesting methyl groups). 
In addition to the characteristics that define the genus, it has the characteristics described below. Cells are non-motile short rods, $0.9-1.0 \mu \mathrm{m}$ in diameter and $1.2-1.8 \mu \mathrm{m}$ in length. Urease- and catalase-positive. Oxidase activity is very low. Optimal growth at $\mathrm{pH}$ $7 \cdot 5-8.0$ and temperatures of $28-30^{\circ} \mathrm{C}$. Utilizable carbon sources are DCM, methanol, methylamine, formate, $\mathrm{CO}_{2} / \mathrm{H}_{2}$, D-glucose, D-fructose, D-mannose, Larabinose, D-xylose, sorbose, ribose, maltose, sucrose, D-sorbitol, D-mannitol, inositol, glycerol, dulcitol, adonitol, ethanol, acetate, 2-oxoglutarate, fumarate, pyruvate, succinate, malate, citrate, oxaloacetate, propionate, cis-aconitate, L-glutamate, L-alanine and acetamide. The following are not utilized: methane, chloromethane, formaldehyde, di- and trimethylamines, thiocyanate, thiosulfate, DMSO and dimethyl acetamide. Yeast extract $(0.01 \%, \mathrm{w} / \mathrm{v})$ or a biotin/ thiamin mixture (both at $20 \mu \mathrm{g}^{-1}$ ) stimulates growth. Resistant to penicillin and rifampicin, but sensitive to gentamicin, kanamycin, ampicillin, neomycin, novobiocin, nalidixic acid, tetracycline and lincomycin. The DNA $\mathrm{G}+\mathrm{C}$ content is $66.7 \mathrm{~mol} \%$ ( $T_{\mathrm{m}}$ method). The type strain, DM10 $0^{\mathrm{T}}\left(=\mathrm{VKM} \mathrm{B}-2236^{\mathrm{T}}=\mathrm{DSM}\right.$ $13819^{\mathrm{T}}$ ), was isolated in Switzerland from ground water contaminated with DCM.

\section{ACKNOWLEDGEMENTS}

This work was funded by grant INTAS 94-3122.

\section{REFERENCES}

Brunner, W., Staub, D. \& Leisinger, T. (1980). Bacterial degradation of dichloromethane. Appl Environ Microbiol 40, 950-958.

Denhardt, D. T. (1966). A membrane-filter technique for the detection of complementary DNA. Biochem Biophys Res Commun 23, 641-646.

Doronina, N. V. \& Trotsenko, Y.A. (1994). Methylophilus leisingerii-a new species of restricted facultatively methylotrophic bacteria. Microbiology (English translation of Mikrobiologiya) 63, 298-302.

Doronina, N. V., Trotsenko, Y. A. \& Leisinger, T. (1992). Metabolic characterization of aerobic dichloromethane-utilizers. In Microbial Growth on C1 Compounds. Abstracts of the 7th International Symposium,Warwick, UK, A13.

Doronina, N. V., Braus-Strohmeyer, S. A., Leisinger, T. \& Trotsenko, Y. A. (1995). Isolation and characterization of a new facultatively methylotrophic bacteria: description of Methylorhabdus multivorans gen. nov., sp. nov. Syst Appl Microbiol 18, 92-98.

Doronina, N. V., Trotsenko, Y. A., Krausova, V. I. \& Suzina, N. E. (1998a). Paracoccus methylutens sp. nov. - a new aerobic facultatively methylotrophic bacterium utilizing dichloromethane. Syst Appl Microbiol 21, 230-236.

Doronina, N. V., Trotsenko, Y. A., Krausova, V. I., Boulygina, E. S. \& Tourova, T. P. (1998b). Methylopila capsulata gen. nov., sp. nov., a novel non-pigmented aerobic facultatively methylotrophic bacterium. Int J Syst Bacteriol 48, 1313-1321.

Doronina, N. V., Trotsenko, Y. A., Tourova, T. P., Kuznetsov, B. B. \& Leisinger, T. (2000). Methylopila helvetica sp. nov. and
Methylobacterium dichloromethanicum sp. nov. - novel aerobic facultatively methylotrophic bacteria utilizing dichloromethane. Syst Appl Microbiol 23, 210-218.

Gaelli, R. \& Leisinger, T. (1985). Specialized bacterial strains for the removal of dichloromethane from industrial waste. Conserv Recycl 8, 91-100.

Gordon, S. A. \& Weber, R. P. (1951). Colorimetric estimation of indolacetic acid. Plant Physiol 26, 192-195.

Jukes, T. H. \& Cantor, C. R. (1969). Evolution of protein molecules. In Mammalian Protein Metabolism, vol. 3, pp. 21-132. Edited by H. N. Munro. New York: Academic Press.

Kersters, K. \& De Ley, J. (1984). Genus Alcaligenes Castellani and Chalmers 1919, 936 ${ }^{\mathrm{AL}}$. In Bergey's Manual of Systematic Bacteriology, vol. 1, pp. 361-373. Edited by N. R. Krieg \& J. G. Holt. Baltimore: Williams \& Wilkins.

Lane, D. J. (1991). 16S/23S rRNA sequencing. In Nucleic Acid Techniques in Bacterial Systematics, pp. 115-147. Edited by E. Stackebrandt \& M. Goodfellow. New York: Wiley.

Leisinger, T., Bader, R., Hermann, R., Schmid-Appert, M. \& Vuilleumier, S. (1994). Microbes, enzymes and genes involved in dichloromethane utilization. Biodegradation 5, 237-248.

Mägli, A., Messmer, M. \& Leisinger, T. (1998). Metabolism of dichloromethane by the strict anaerobe Dehalobacterium formicoaceticum. Appl Environ Microbiol 64, 646-650.

Marmur, J. A. (1961). A procedure for the isolation of deoxyribonucleic acid from microorganisms. J Mol Biol 3, 208-214.

Owen, R. J. \& Lapage, S. P. (1976). The thermal denaturation of partly purified bacterial deoxyribonucleic acid and its taxonomic applications. J Appl Bacteriol 41, 335-340.

Raj, H. D. (1981). The genus Microcyclus and related bacteria. In The Prokaryotes - A Handbook on Habitats, Isolation and Identification of Bacteria, pp. 630-644. Edited by M. P. Starr, H. Stolp, H. G. Trüper, A. Balows \& H. G. Schlegel. New York: Springer.

Raj, H. D. (1983). Proposal of Ancylobacter gen. nov. as a substitute for the bacterial genus Microcyclus Ørskov 1928. Int J Syst Bacteriol 33, 397-398.

Saitou, N. \& Nei, M. (1987). The neighbor-joining method: a new method for reconstructing phylogenetic trees. Mol Biol Evol 4, 406-425.

Scholtz, R., Wackett, L. P., Egli, C., Cook, A. M. \& Leisinger, T. (1988). Dichloromethane dehalogenase with improved catalytic activity isolated from a fast-growing dichloromethane-utilizing bacterium. J Bacteriol 170, 5698-5704.

Sly, L. I. (1985). Emendation of the genus Blastobacter Zavarzin 1961 and description of Blastobacter natatorius sp. nov. Int $J$ Syst Bacteriol 35, 40-45.

Smibert, R. M. \& Krieg, N. R. (1994). Phenotypic characterization. In Methods for General and Molecular Microbiology, pp. 611-654. Edited by P. Gerhardt, R. G. E. Murray, W. A. Wood \& N. R. Krieg. Washington, DC: American Society for Microbiology.

Stucki, G., Gaelli, R., Ebersold, H.-R. \& Leisinger, T. (1981). Dehalogenation of dichloromethane by cell extract of Hyphomicrobium DM2. Arch Microbiol 130, 366-371.

Trotsenko, Y. A., Doronina, N. V. \& Govorukhina, N. I. (1986). Metabolism of non-motile obligately methylotrophic bacteria. FEMS Microbiol Lett 3, 293-297.

Trotsenko, Y. A., Doronina, N. V. \& Hirsch, P. (1989). Genus Blastobacter Zavarzin 1961, 962 $2^{\mathrm{AL}}$. In Bergey's Manual of Systematic Bacteriology, vol. 3, pp. 1963-1968. Edited by J. T. 
Staley, M. P. Bryant, N. Pfennig \& J. G. Holt. Baltimore: Williams \& Wilkins.

Urakami, T., Araki, H. \& Komagata, K. (1995). Characteristics of newly isolated Xanthobacter strains and fatty acid compositions and quinone systems in yellow-pigmented hydrogen-oxidizing bacteria. Int J Syst Bacteriol 45, 863-867.

Vandamme, P., Pot, B., Gillis, M., De Vos, P., Kersters, K. \& Swings, J. (1996). Polyphasic taxonomy, a consensus approach to bacterial systematics. Microbiol Rev 60, 407-438.

Van de Peer, Y. \& De Wachter, R. (1994). TREECON for Windows: a software package for the construction and drawing of evolutionary trees for the Microsoft Windows environment. Comput Appl Biosci 10, 569-570.
Vasilyeva, L. V. (1989). Genus Angulomicrobium Vasilyeva, Lafitskaya and Namsaraev 1979, 1037 ${ }^{\mathrm{VP}}$. In Bergey's Manual of Systematic Bacteriology, vol. 3, pp. 1969-1971. Edited by J. T. Staley, M. P. Bryant, N. Pfennig \& J. G. Holt. Baltimore: Williams \& Wilkins.

Vasilyeva, L. V., Lafitskaya, T. N. \& Namsaraev, B. B. (1979). Angulomicrobium tetraedrale, a new genus of budding bacteria with radial cell symmetryMicrobiology (English translation of Mikrobiologiya) 48, 843-849.

Wiegel, J. (1992). The genus Xanthobacter. In The Prokaryotes, 2nd edn, vol. 3, pp. 2365-2385. Edited by A. Balows, H. G. Trüper, M. Dworkin, W. Harder \& K.-H. Schleifer. New York: Springer. 